\title{
Modern Operative Treatment of Malleolar Fractures and Associated Consequences (Review)
}

\author{
DOI: $10.17691 /$ stm2015.7.2.20
}

Received June 16, 2014

R.O. Gorbatov, Clinical Resident, Department of Traumatology and Orthopedics";

D.V. Pavlov, PhD, Head of Traumatological and Orthopaedic Department';

E.E. Malyshev, PhD, Associate Professor, Department of Traumatology, Orthopedics and Field Surgery2; Traumatologist and Orthopedist ${ }^{1}$

${ }^{1}$ Privolzhsky Federal Research Medical Center, Ministry of Health of the Russian Federation, 18 Verkhne-Volzhskaya naberezhnaya St., Nizhny Novgorod, 603155, Russian Federation; ${ }^{2}$ Nizhny Novgorod State Medical Academy, 10/1 Minin and Pozharsky Square, Nizhny Novgorod, 603005 Russian Federation

The review covers the current state of the problem of operative treatment of malleolar fractures and the associated consequences. Various methods used in osteosynthesis of the malleolus were analyzed. The main criteria of the favorable arrangement of the fractured bone fragments for malleolus reposition are identified. Methods for recovery of the ligamentous apparatus of the ankle joint are described, that have been neglected by many surgeons, though in $50 \%$ of cases it causes development of chronic instability with further osteoarthrosis. The reason for large number of poor outcomes of malleolar fracture treatment is defined, which occur despite the anatomically precise reposition, recovery of the ligamentous apparatus and good postoperative care of patients. All this is mainly due to presence of post-traumatic articular cartilage defects that further induce development of osteoarthrosis. The main techniques used for arthroscopic treatment of this pathology are described, including that with the autologous chondrocyte implantation. Attention is given to the subject of primary and revision replacement of the ankle joint, the long term results in comparison with replacement of knee and hip joints are shown. The modern and most efficient techniques of the ankle joint arthrodesis are presented, including arthrodesis with a retrograde intramedullary rod and arthroscopic arthrodesis. The main techniques used for treatment of the post-traumatic ankle joint arthrosis are identified depending on its stage.

Key words: malleolar fracture; ankle joint osteoarthrosis; total ankle replacement; arthroscopy of the ankle joint; osteosynthesis of the malleolus; retrograde intramedullary arthrodesis.

In the structure of locomotor system injuries, malleolar fractures are among the most frequently occurring and the most significant ones in terms of their anatomic and functional consequences. The occurence rate is 174 fractures per 100,000 persons, the average age when these fractures occur is 45.9 , in the structure of all fractures this injury type amounts to $9 \%$ [1-3]. Despite there is a large variety of conservative and surgical treatment techniques for these injuries, the number of poor outcomes reaches 7-38\% [4-6], and in cases with severe pronation fractures it grows up to $40 \%$ [7]. In 60 $70 \%$ cases, injuries of this area occur in working-age people. In $60 \%$ cases, injuries of the ankle joint leads to development of arthrosis [8-10]. The occurrence rate depends on the fracture type: with malleolar fracture of the A-type (as defined by the International AO/ASIF Classification) $-4 \%$, with malleolar fracture of the Ctype - up to $33 \%$ [11]. Disablement in patients with this pathology reaches $8.8-46 \%[4-6]$, and in cases of injuries with disruption of the distal tibiofibular syndesmosis - 61\% [7]. Despite achievements of the modern medicine, up to $50 \%$ of patients with injuries of the ankle joint ligaments receive treatment that proves inefficient and causes development of chronic instability of the ankle joint and rapid osteoarthrosis development [12]. There is also injury of articular surface of the talus bone associated with malleolar fractures (up to $73 \%$ cases), that tends to be left undiagnosed quite often [13]. Therefore, treatment of malleolar fractures is subject to a number of difficulties related to character of the fracture, functional significance of the ankle joint and unfavorable biomechanical conditions affecting the articular surface after injury. Furthermore, unlike other joints of the body, the ankle joint is subject to the highest load per square centimeter of the articular surface. Both intra-articular and juxta-articular injuries require precise anatomical reposition and ensuring early functionality to recover the complete support ability of the limb. III-timed recognition and inadequate treatment of such injuries cause unfavorable outcomes [11, 14]. Moreover, results of the analytical studies $[4,5,15,16]$ showed that conservative treatment of malleolar fractures that are not accompanied with displacement of bone fragments or when displacement does not exceed 1-2 mm, 12$17 \%$ patients experience rapid development of posttraumatic osteoarthrosis or significant progress of

For contacts: Gorbatov Roman Olegovich, e-mail: gorbatov.ro@yandex.ru 
existing degenerative-dystrophic changes. This is due to two factors: articular cartilage is damaged by injury and the capsular-ligamentous apparatus often does not recover, resulting in instability and/or incongruence of the joint. Early and technically correct operation is much safer and results in fewer complications than closed reposition [17-19].

\section{Operative treatment of malleolar fractures}

Isolated infrasyndesmotic injuries (A-type, as defined by the International AO/ASIF Classification) to the distal portion of the fibula without medial side damage and isolated nondisplaced transsyndesmotic fractures (B-type, as defined by the AO/ASIF Classification) of the lateral malleolus with the medial side left undamaged can be relatively stable and subject to conservative treatment. In other cases operative treatment is indicated because generally only open reposition and stable internal fixation can guarantee precise anatomical recovery [20,21].

The following operative fixation devices are used $[7$, 11, 19, 20, 22-26]:

- for the lateral malleolus fracture - plates, screws, rods, Weber's osteosynthesis, wire cerclage systems (in particular cases), titanium nickelide devices with shape memory;

- for the medial malleolus fracture - screw, plate, screw with a pin, Weber's osteosynthesis, transosseous wire suture, twisted thread suture (in particular cases of splintered fractures), titanium nickelide devices with shape memory;

- for the fracture of distal metaepiphysis of the tibia - screws, pins (including transcutaneous), Weber's osteosynthesis, supporting plates, in particular cases rods, other plates, lag screw;

— for the fracture of distal tibiofibular joint — ligament suturing, lag screw, screws, sometimes combined with plates or special covers, clamp-like holding device with screws, titanium nickelide devices with shape memory, in particular cases wire (also combined with pecial covers), alloplasty of ligaments.

A reasonable approach to the choice of fixation technique in every particular case allows to use any of the methods described.

When dealing with bone tissue defects and treating old injuries, various techniques of osteoplasty and tenoplasty are used.

The most favorable time to perform osteosynthesis is $6-8 \mathrm{~h}$ after the injury. Control on fracture union after osteosynthesis is carried out using clinical, radiological and radiothermometric methods [20, 27, 28].

Purposes of operative treatment of the malleolus [11, 23, 27]:

anatomically precise bone reconstruction, especially fibula;

reconstruction of the capsular-ligamentous apparatus and the syndesmosis; removal of loose cartilage fragments;

stable osteosynthesis enabling functional treatment.

Position of the bone elements of the ankle joint must meet the following criteria [11, 19, 20, 29, 30]:

1) the tibial axis is perpendicular to line of the ankle joint, inclination of the talus bone is zero degree;

2) stability indicators for the distal tibiofibular joint: tibiofibular clear space on the simple anteroposterior radiograph, measured $1 \mathrm{~cm}$ proximal of the joint cavity - less than $5 \mathrm{~mm}$; tibiofibular overlap measured $1 \mathrm{~cm}$ proximal of the tibial plafond on the simple anteroposterior radiograph - more than $10 \mathrm{~mm}$, while on the radiograph with internal rotation - more than $1 \mathrm{~mm}$;

3) uniformity of the joint cavity: medial joint cavity equal to the joint cavity between the cupula of the talus and arch of the tibia;

4) allowed displacement of the medial malleolus in any direction - no more than $2 \mathrm{~mm}$, of the distal end of the fibula at the site of fracture - less than $2 \mathrm{~mm}$;

5) displacement of the posterior border of the tibia fragment - less than $2 \mathrm{~mm}$, with the posterior border of the tibia fragment less than $1 / 4$ of the articular surface displacement (or less than $25 \%$ of the articular surface displacement on the lateral radiograph) any displacement can be neglected.

In the standard approach, first the tibial shortening and its rotational displacement are eliminated, then follow tibiofibular syndesmosis reconstruction and osteosynthesis of the posterior border of the tibia fragment, and finally fixation of the medial malleolus or suture of the deltoid ligament [7, 19, 23, 24].

In operative treatment of the lateral malleolus, external approach is generally used: a straight incision slightly posterior of the fibula. Care should be taken not to damage the superficial peroneal nerve, which lies closely anteriorly of the lateral malleolus [20, 31-33].

In treatment of the A-type fractures according to the AO/ASIF Classification, bone fragments may be secured using pins and wires or malleolar screw [20, 27] (Figure 1).

In treatment of the B- and C-type fractures according to the AO/ASIF Classification, extracortical osteosynthesis is performed with application of a one third tubular or reconstructive plate (standard plates or their angle-stable versions that are recommended to place somewhat posteriorly of the fibula) $[7,20,23,24$, 27, 34] (Figure 2).

Recently, the minimally invasive percutaneous plate osteosynthesis (MIPPO) technique has been increasingly used, that minimizes the damage of soft tissues, reduce post-operative complications and ensure earlier functional load on the joint [35, 36]. In the study that involved 12 months of observation of patients, Pires et al. [37] obtained more than $90 \%$ of good and excellent results, according to the AOFAS scale - the average of 88.3. Kim et al. [38] obtained different results (AOFAS - 


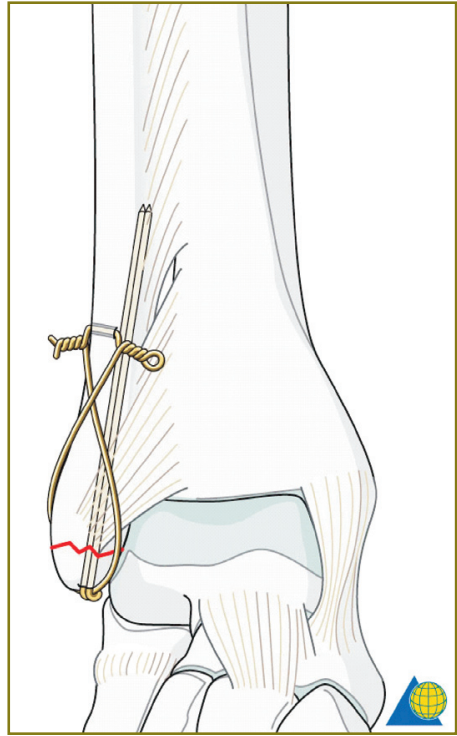

Figure 1. Avulsion fragment is first stabilized with two K-wires fixed under compression by means of a tension with a wire loop [20]

the average of 97.1) using T-LCP plates to fix the A- and B-type fractures.

In treatment of lateral ligaments on the outside of the ankle joint, tendon suture, plasty with the use of muscle tendons autografts, plasty with allografts (most commonly used grafts are those containing Carbon fiber, such as Linaphil (B. Braun Melsungen, Germany). The most commonly used technique is tenoplasty by Evans and Watson-Jones procedures (plasty with the short peroneal muscle) [39]. In his study Krips et al. [40] proved that even after ten years of observation anatomical reconstruction of tendons gives much better results than the results of plasty with allografts.
Therefore, tendon suture or the trans-osseous reinsertion of tendons with regard to their attachment points as well as their physiological extension range do not cause any constraints to the normal biomechanics of ankle joint (unlike various techniques of auto- and alloplasty) and can be considered a treatment of choice in reconstruction surgery on the lateral ligamentous apparatus [39, 41, 42].

Posterior lip of the tibial arch, the so called posterior malleolus or Volkmann's triangle, is often involved in the process in malleolar injuries. If the fracture of the posterior border of the arch affects $1 / 4$ of articular surface it needs to be reduced and fixed to avoid posterior subluxation of the talus bone and incongruity of the joint. Posterolateral approach is recommended: incision between the Achilles tendon and peroneal muscle tendons [20, 43-46]. Fixation with one or two spongious or cortical screws under control in electro-optical converter is recommended [19, 20, 47, 48] (Figure 3).

As for choice of technique for operative fixation in cases of disruption oftendons of the distal tibiofibularsyndesmosis, it should be noted that there are various ways to hold tibia and fibula together: ligament suturing, use of auto- and alloplasty, or position screw. However, the best results (based on the time when the movements start, number of post-operative complications) were obtained when screw fixation was used (more than $90 \%$ of good and excellent results, according to the AOFAS and the FAAM scales) [49-53]. Allowing to apply considerable apposition force to tibia and fibula, the position screw causes little damage to bone and paraosseous soft tissues, and, above all, to ligament fibers in the tibiofibular gap. Holding the tibia and fibula in apposition, the position screw does not impair mutual mobility both in vertical and sagittal directions, that is physiologically significant for the ankle

Figure 2. Oblique fracture is compressed with a $3.5 \mathrm{~mm}$ (or $2.7 \mathrm{~mm}$ ) cortex lag screw inserted anterior to posterior or posterior to anterior, and this fixation is protected with a one third tubular plate bent along the exterior portion of the fibula [34]
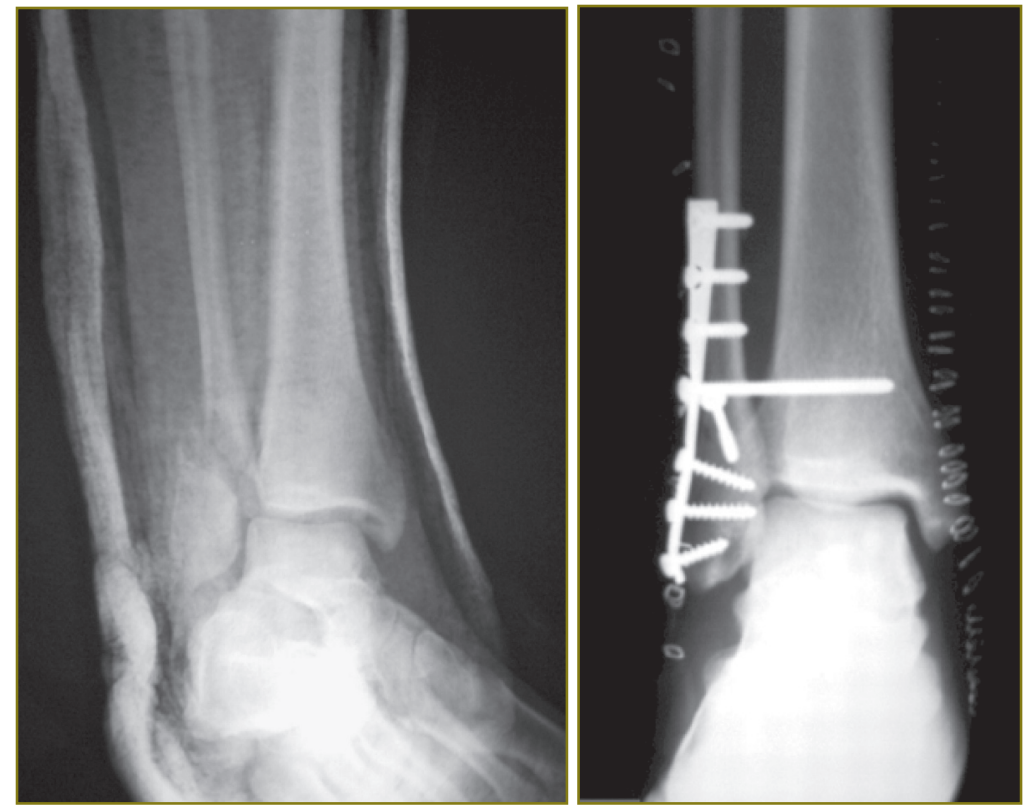

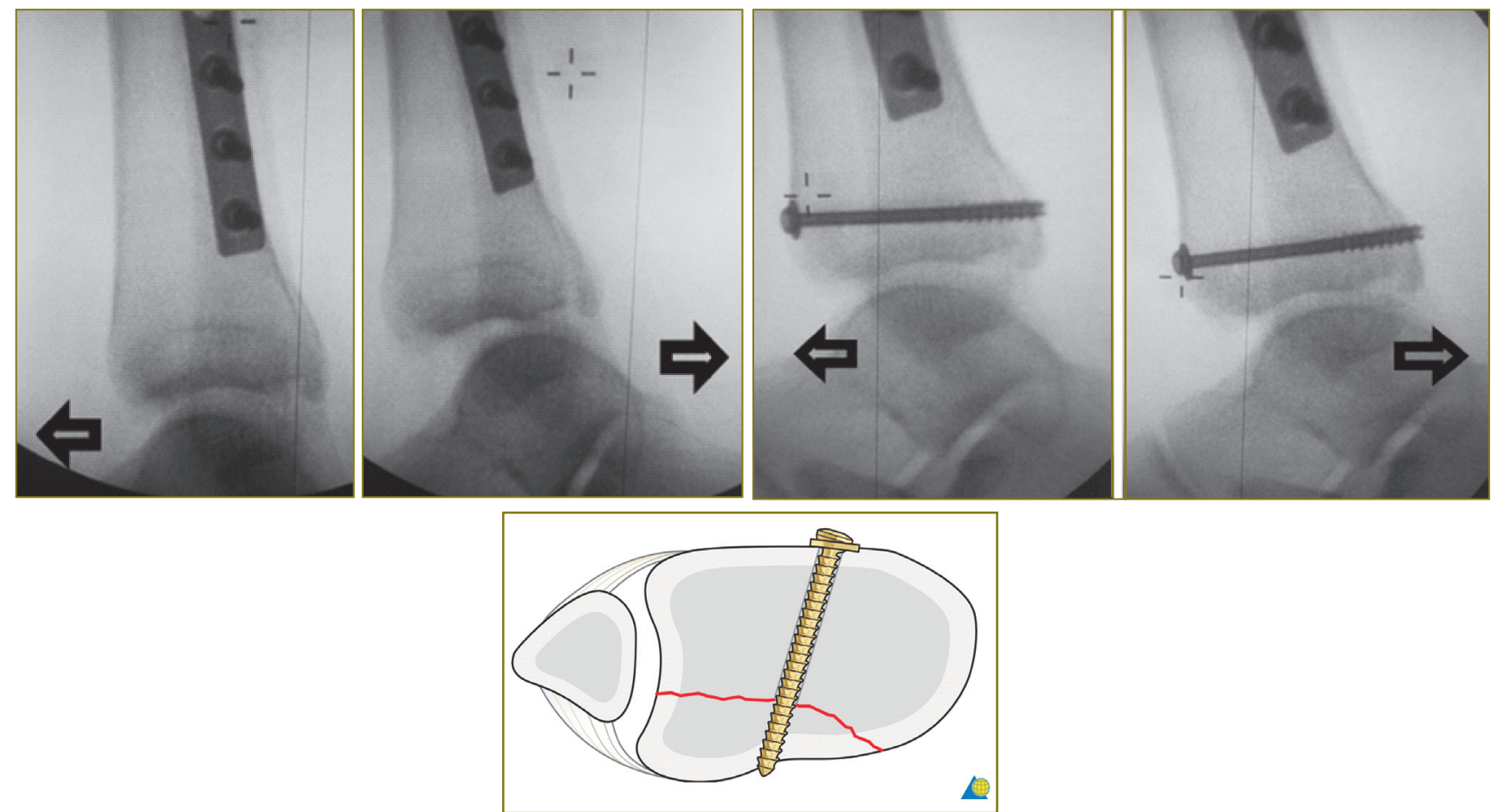

Figure 3. Posterolateral fragment is carefully reduced and then fixed with a 4.0-mm spongious screw inserted anterior to posterior or posterior to anterior. For small fragments, a $3.5-\mathrm{mm}$ cortex screw can be used as a tensioning device. Please pay attention to the direction of its insertion for the fragment often has a posterolateral position) [20, 48]

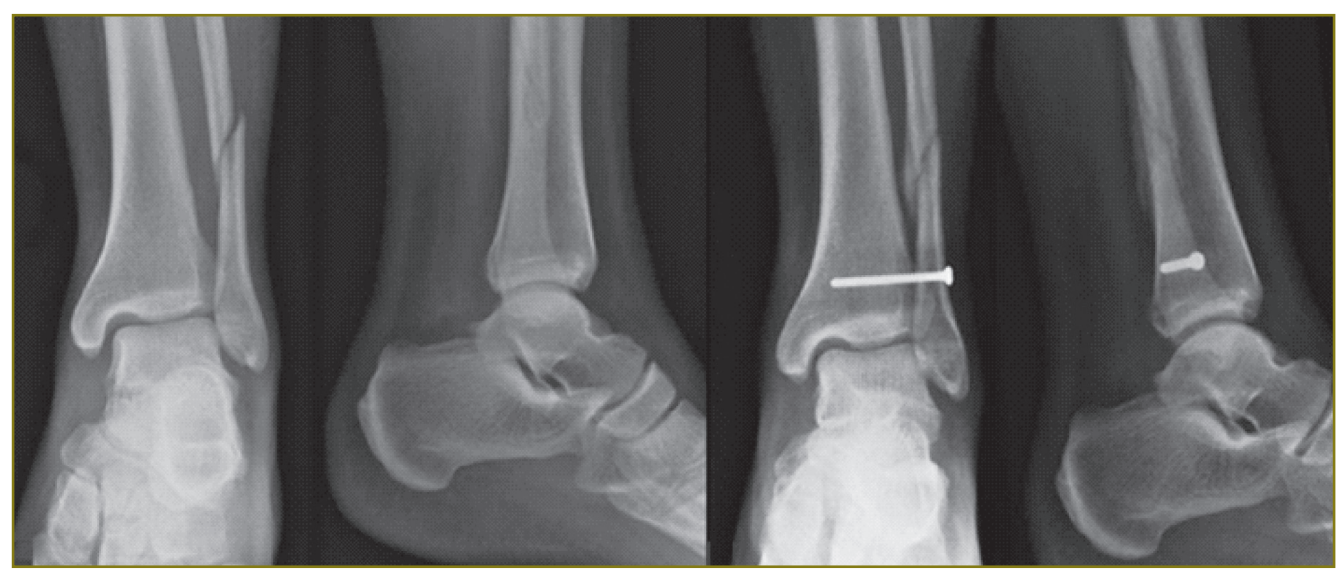

Figure 4. Position screw inserted posterior to anterior at an angle of $25^{\circ}[54]$

joint functionality during the post-immobilization period. This structure ensures the simplest way to measure and correct the degree of approximation between tibia and fibula during surgery.

As in the vertical direction the fibular notch of the tibia forms not a straight vertical line, but rather a curve with an outwardly protruding bulge, the optimal adaptation of the supporting elements with the fixation device is achieved when it is inserted posterior to anterior in a slantwise direction at an angle of $25-30^{\circ}$ in relation to the horizontal axis (perpendicular to the medial surface of the distal metaepiphysis of the tibia) and the screw head is placed on the fibular side $2 \mathrm{~cm}$ proximal of the tibiofibular joint. There is no consensus yet on whether one or two cortical layers of the tibia shall be engaged by the position of the screw thread. A recent study supports the use of tricortical screws with no increase in complications [7, 20, 23, 24, 54, 55] (Figure 4).

In cases of old ruptures of the tibiofibular syndesmosis, the latter is formed by scar tissue that is incapable to hold tibia and fibula firmly. Therefore, the surgery requires complete resection of the scar tissue and careful exposition of the fibular notch of the tibia with further fixation of the tibiofibular syndesmosis using the position screw. 

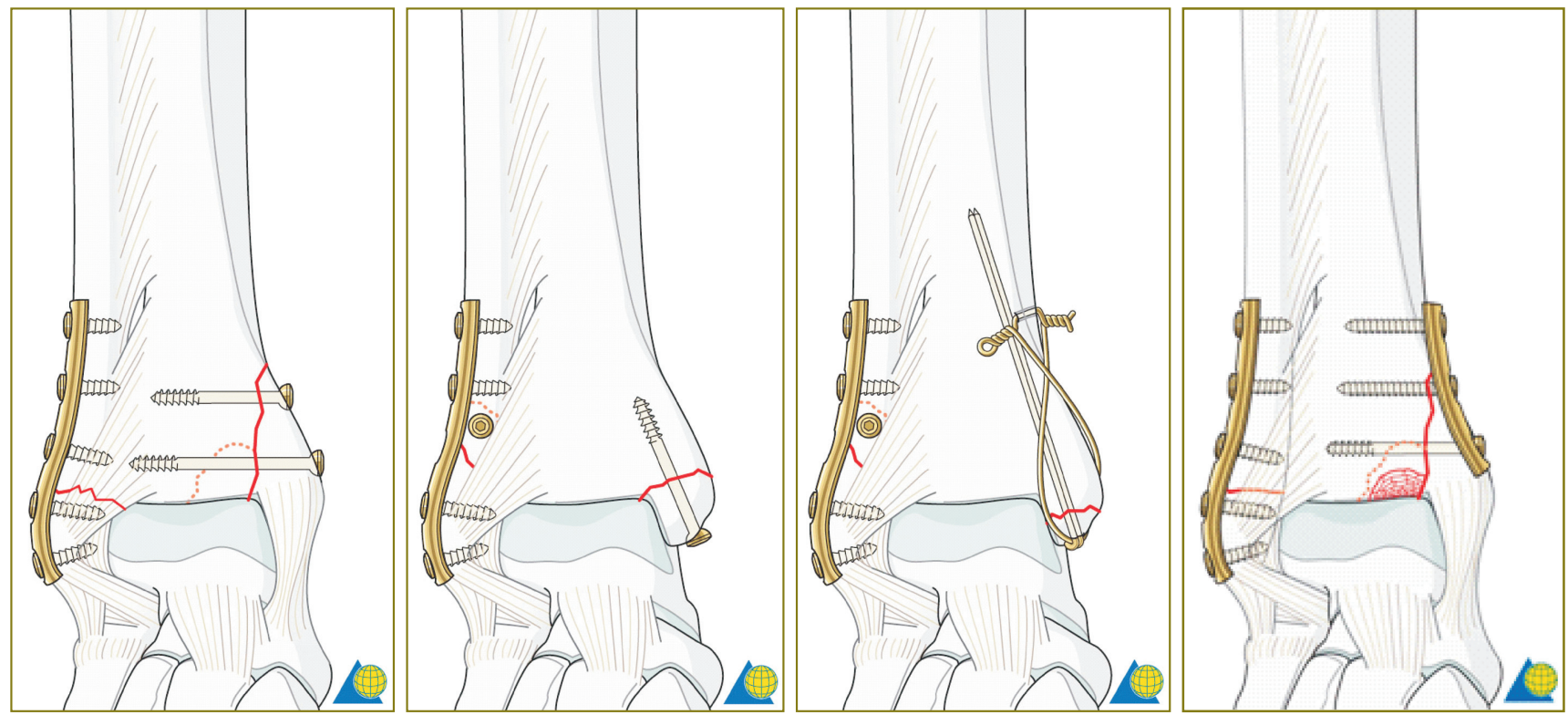

Figure 5. Various methods of the medial malleolus fixation [20]

Furthermore, use of tensioning devices with local force application may potentially cause valgus angulation of the fibula distal fragment when the screw is tightened. Valgus position of the lateral malleolus results in dysfunction of the ankle mortise, appearance or retention of the talus bone pronational subluxation and renders any surgical intervention senseless. Prevention of this displacement includes fibular osteosynthesis with structures that ensure stable fixation of fragments and tensioning of the tibiofibular syndesmosis with the angle of $90^{\circ}$ flexion at the ankle joint (back edge of the talus bone will dose the compression applied) $[7,20,27,56]$.

For operative treatment of the medial malleolus, medial approach is generally used: incision placed slightly posterior of the medial malleolus along the tibia with a distal J-shaped curve [20,57-59].

The most reliable fixation device for the medial malleolus is the screw $[7,20,23,27]$, that is inserted in the meta-epiphyseal portion of the tibia parallel to the joint cavity in treatment of the A-type fractures according to the AO/ASIF Classification, and from the top of the medial malleolus perpendicular to the fracture line in treatment of the B- and C-type fractures. Use of a single screw permits rotational instability, so a second Kirshnerwire is inserted parallel to the screw. Osteosynthesis with pins is recommended for fractures with small fragments that may be further split. Pins are inserted either crosswise or parallel. In the latter case fixation should be supplemented with an 8-shaped transosseous wire or strong thread suture. This technique (of the Weber's osteosynthesis type) allows to hold fragments securely even when the medial malleolus is split in two pieces. Pins fixed transosseously are removed in 35 weeks. Later on, there is no need to repeat surgical intervention to remove metal structures. Along the use of osteosynthesis techniques, one must not ignore the possibility to fix the medial malleolus with a suture. In the area of proximal fragment, a transosseous suture must be used, while in the area of distal fragment a twisted (with fixation through the soft tissues), interrupted transosseous or 8-shaped suture, or a combination of two suture types can be used. Despite its lower stability, this technique allows to achieve quite a successful retention of fragments in treatment of comminuted fractures, or in case of medial malleolus splitting during surgery, as well as small fragment fractures. For larger fractures, a threehole one third tubular plate fulfilling support function may be used [7, 20, 22, 23, 25, 27, 60] (Figure 5).

Deltoid ligament injuries usually do not require operative treatment. However, if the medial joint cavity remains widened after reposition of the fibula fracture using an intraoperative radiograph, or precise reposition of the lateral malleolus is hindered, surgical revision of the medial side is recommended. Recent ruptures of the deltoid ligament are joined by PET-sutures or reconstructed using local tissues; in old ruptures, plasty by auto- or allografts is performed (the most commonly used type is plasty by anterior portion of the posterior tibial muscle ligament) $[7,19,20,25,27,61]$.

\section{Operative treatment of malleolar fracture consequences}

In treatment of malleolar fracture consequences the following operative interventions are performed:

reconstruction surgery, including decompression of the ankle joint, the joint arthroplasty and its endoprosthesis replacement; 
stabilizing operations (arthrodesis, tenodesis, arthrorisis).

Endoprosthesis replacement of the ankle joint is currently one of the most complex, painstaking and poorly studied problems. Challenges related to the endoprosthesis replacement of the ankle joint are mainly caused by the complexity of its anatomical structure, diversity of its functions and huge staticodynamic loads, that according to different authors vary from 3 to 13.5 of the body weight $[62,63]$. Complexity of the ankle joint biomechanics, necessity to consider the functional status of the talocalcaneal joint and variability of the axis geometry and the normal movement amplitude make it very difficult to produce the prosthesis that would replace the joint in any person $[7,62,63]$.

There are two basic endoprosthesis groups coupled and uncoupled. Coupled endoprosthesis can not compensate for all mechanic features of the joint, that is why maximum load occurs in the fixation sites, especially where the bone cement contacts with the bone, what causes its early instability. Currently uncoupled endoprostheses are used. Their use is often associated with the impingement syndrome, but the load on the bone in the fixation sites is lower, so the long term results are better. Based on the movement mode these endoprostheses are classified into singleaxis (Mayo, TPR, Buchholz, Oregon, Grundaj, Loskutov etc.) and multiaxis (Smith, Newton, STAR, Agiliti, Hintegra etc.). Multiaxis structures give better results, especially for rigid (rheumatoid) rear part of the foot, when restoration of supination and pronation reduces the load that cause mechanical loosening. Uncoupled prostheses are subdivided into two-component and three-component, cemented and uncemented. The best results were achieved with the uncemented threecomponent endoprosthesis HINTEGRA (NewDeal SA, France) (Figure 6) having five-year survival rate of $98 \%$, and the STAR endoprosthesis $(72.7 \%)[7,64-66]$.

Today the ten-year survival rate of the uncemented endoprosthesis is observed in more than $80 \%$ of cases $[62,63]$. For reference: in the hip joint, considered the most "suitable" for endoprosthesis replacement, the 10-year survival rate of the uncemented prosthesis is $88-91 \%$ (results obtained in more than 280,000 observations) [67]. The average range of motion in the ankle joint after endoprosthesis replacement is $27.2^{\circ}$, and though it is less than in the healthy joint, it is generally accepted that the normal act of walking can be accomplished with at least $25^{\circ}[63,68,69]$. Rate of good and excellent results on the AOFAS scale is 75\% [63]. The most common complication after endoprosthesis replacement of the ankle joint is a stress fracture of the malleolus with the occurence rate that may reach $20 \%$ [70]; however, plaster immobilization is helpful to achieve fracture union in most cases [63].

Other complications after endoprosthesis replacement include protrusion and instability, especially of the endoprosthesis' tibial component, heterotopic ossification, synovitis, exostosis of the malleolus impairing walking, osteoporosis of bone tissue on the site of cement fixation etc. [7]. According to different authors, a revision surgery rate of after endoprosthesis replacement is $4-24 \%$ and involves replacement of the polyethylene insert, osteotomy of anterior or posterior impingement, ligament reconstruction, osteotomy of the calcaneal bone, subtalar arthrodesis, lengthening or shortening of the fibula, achillotomy, osteosynthesis of the peri-prosthetic fracture $[1,68,69,71-74]$. For reference: revision endoprosthesis replacement of the hip joint is $14.4 \%$, revision endoprosthesis replacement of the knee joint $-7.3 \%$ [75].

Corrective and reconstructive-reparative surgery is one of the promising directions in treatment of malleolar fracture consequences. Corrective operations are indicated for pseudarthrosis, malunions following a malleolar fracture with valgus or varus foot position. Moreover, when deformed after injury, biomechanical axis of the lower limb under load intensifies degeneration of the injured articular cartilage, what highlights the necessity to perform these operations, whose effectiveness, according to literature data, is $75-90 \%$ [76-81]. There are several types of the fibula (transverse, oblique, Z-type, or along the fracture line) and the tibia (wedge and angle) osteotomy. Each

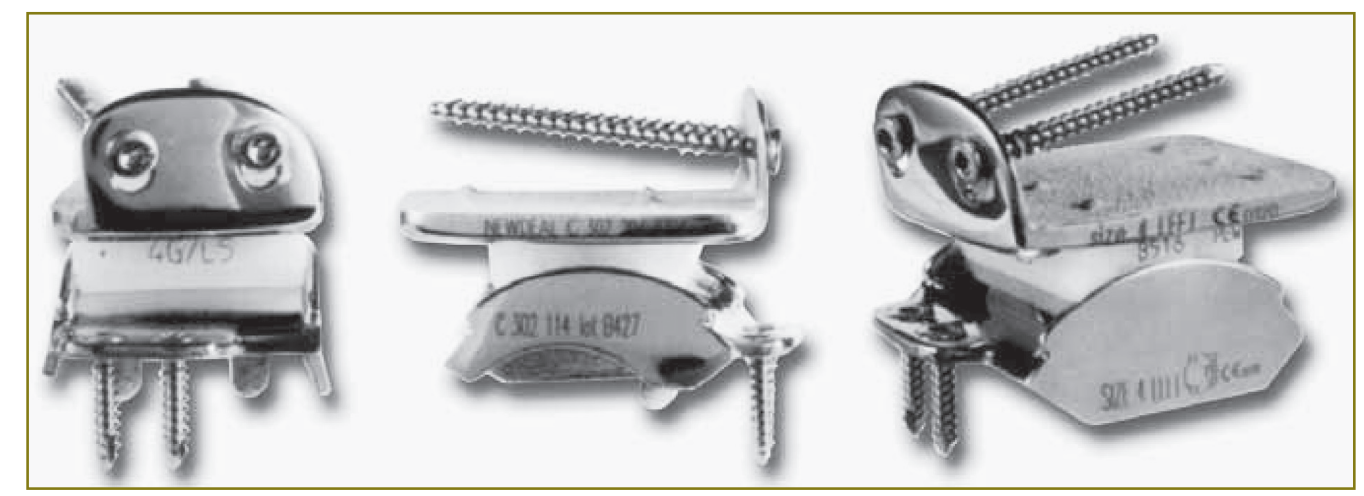

Figure 6. Uncoupled three-component endoprosthesis of the ankle joint HINTEGRA [64] 
of this options has its advantages and disadvantages, and none is the optimal one in all the clinical cases. But lengthening and shortening osteotomy types are used. Malleolar lengthening can be achieved using autograft taken locally or from the iliac crest, allograft or with bone substitute. Through corrective osteotomy, decompression of the damaged articular surfaces is achieved to prevent their traumatic contact when the joint moves and slow down (or stop altogether) osteoarthrosis development. Load on the joint is reduced and it receives additional blood supply through the malleolar bone graft, the range of motion increase. Reconstructive-reparative operations are performed to recover congruence of articular surface and the ligamentous apparatus of the ankle joint [7, 76-82].

For treatment of the post-traumatic ankle joint arthrosis, arthroscopy has been coming into use, for it is not only helpful to visualize defects of articular surface but can be used as a separate treatment technique. Arthroscopy includes [11, 76, 79, 83-86]:

- debridement of the injured articular cartilage;

- resection of osteocartilaginous exostoses, mechanical smoothing out (using a shaver) marginal erosions, frayed cartilages, visible rough edges and cracks to improve sliding and friction conditions in the damaged joint;

- removal of cartilage flaps, osteophytes;

- excision and removal of adhesions and hypertrophic synovial membrane;

- stimulation of the cartilage regeneration through perforation of subchondral bone and/or curettage of the chondral defect area;

- removal of anterior or posterior impingement;

- replacement of chondral defects with cell implants [87], especially good results were obtained with matrixinduced autologous chondrocyte implantation (Maci): improvement of indicators, as assessed by AOFAS scores in 1 year, from 61.2 to 75 [88].

In patients with post-traumatic chondral defects of the talus bone up to $15 \mathrm{~mm}$ in diameter, debridement with further perforation of subchondral bone is recommended to stimulate the cartilage regeneration. For defects larger than $15 \mathrm{~mm}$, fixation or curettage and perforation with further replacement with cell implants or autologous chondrocyte implantation must be used (ACI) [89-91].

As external distractors, both monolateral rod-type distractors can be employed: Orthofix (Italy) and others [79], that are removed in 4 weeks after placement, as well as loop and manual distraction techniques [76, 83, 84].

In treatment of the post-traumatic arthrosis, grade I-II (according to the Kellgren and Lawrence classification), with remaining articular surface congruence and unaltered biological axis of the ankle joint, arthroscopy provided $96 \%$ of good and excellent results with full recovery of working capacity in all patients (7-year observation) [79].
The number of arthrodeses performed is steadily decreasing all over the world, because this operation ultimately results in the functional insufficiency of the foot, loss of balance of its compensatory functions, as well as arthrosis deformans of all foot joints accompanied by pain syndrome [7, 92-94]. Rate of post-operative complications after arthrodesis reaches $60 \%$, average rate of pseudarthrosis development is $20 \%$, average rate of infectious complication - 5 to $20 \%$ [76]. Many arthrodesis techniques have been developed, that can be subdivided into compression and non-compression. The most widely used is non-compression arthrodesis by Vreden's and Campbell's technique, in cases of severe injuries of the tibia and talus bone epimetaphys Caplan's arthrodesis. Compression arthrodesis is performed with various devices: Grishin's, Ilizarov's apparatus etc. [7, 95, 96]. Resection of the articular surfaces is performed not only with the oscillating saw and chisel, but also with a less invasive hollow cutter [97]. Good results were obtained with arthrodesis with an intramedullary rod [98-101]: in his study Jehan et al. [98] analyzed 659 arthrodesis operations, where in $86.7 \%$ of cases bony ankylosis developed, that does not require further repeated surgical interventions. The highest stability and lower number of post-operative complications were obtained with arthrodesis with the retrograde intramedullary rod HAN (Synthes, Switzerland), in comparison with its analogue, the most commonly used A3 Fusion Nail (Small Bone Innovations, USA), whose only difference is an additional distal bend and absence of the second calcaneal screw [102]. Recently, arthrodesis using an arthroscopic method has been increasingly used, for it allows to reduce the time needed for bony ankylosis to form (the average of 8.7 weeks after the operation; with traditional open techniques - in 14.5 weeks) and increase the number of good and excellent results to 97\% [76]. Moreover, reports emerged of the ankle joint arthrodesis performed by computer navigation that helped to achieve highly precise apposition of the joint components and reduce the operation time [103].

Conclusion. Despite a significant progress in the operative treatment of malleolar fractures and appearance of new techniques and fixation devices, this problem remains topical. However, development of arthroscopy, endoprosthesis replacement, computer navigation and cell technologies enable surgeons to eliminate adverse outcomes of this pathology. In the course of time fundamental priorities in surgical treatment of malleolar fracture consequences change, for example, just a few years ago arthrodesis was considered the gold standard of the grade III ankle joint osteoarthrosis treatment, while now this pathology is treated with endoprosthesis replacement that helps to preserve the range of motion in the joint. Our analysis of literature revealed many cases when anatomically precise reposition was achieved, ligamentous apparatus 
recovered and good postoperative care provided, but ultimately patient's condition aggravated and arthrosis deformans developed. It is due to post-traumatic articular cartilage defects that further induce osteoarthrosis development. In the light of development of modern technologies, this problem may be solved through the arthroscopic replacement of articular cartilage defects with biological cell-derived implants.

Based on the conducted analysis of contemporary literature, main directions in treatment of malleolar fracture consequences can be identified:

1 ) in cases of the grade I-II osteoarthrosis (according to the Kellgren and Lawrence classification), if congruence of articular surface and biological axis of the ankle joint is recovered, diagnostic and treatment arthroscopy is recommended;

2) corrective and reconstructive-reparative operations should be used to recover anatomy and biomechanics of the ankle joint - this surgical intervention is not only a necessary stage before arthroscopy, endoprosthesis replacement, arthrodesis, but can be used as a separate and final treatment technique for the post-traumatic ankle joint arthrosis, grades I, II, III (according to the Kellgren and Lawrence classification);

3 ) endoprosthesis replacement of the ankle joint is recommended for osteoarthrosis grades III-IV (according to the Kellgren and Lawrence classification), and only when endoprosthesis replacement is impossible, arthrodesis of the ankle joint should be performed.

Study Funding and Conflict of Interests. The study was not funded by any sources, and there are no conflicts of interest related to this study.

\section{References}

1. Lehtonen H., Järvinen T.L.N., Honkonen S., Nyman M., Vihtonen K., Järvinen M. Use of a cast compared with a functional ankle brace after operative treatment of an ankle fracture. J Bone Joint Surg Am 2003 Feb; 85(2): 205-211.

2. Court-Brown C.M., Caesar B. Epidemiology of adult fractures: a review. Injury 2006; 37(8): 691-697, http://dx.doi. org/10.1016/j.injury.2006.04.130.

3. Franke J., von Recum J., Suda A.J. Intraoperative three-dimensional imaging in the treatment of acute unstable syndesmotic injuries. J Bone Joint Surg Am 2012 Aug; 94(15): 1386-1390, http://dx.doi.org/10.2106/JBJS.K.01122.

4. Omelchenko T.N. Ankle fractures and rapidly progressing osteoarthrosis of the ankle joint: prevention and treatment. Ortopediya, travmatologiya i protezirovanie 2013; 4(593): 35-40.

5. Yaremenko D.A., Shevchenko E.G., Tarshis V.B. Intraarticular damages of the lower limbs as a cause of persistent disability. Ortopediya, travmatologiya i protezirovanie 1994; Suppl: 46-47.

6. Rolik O.V., Zasadnyuk I.A. Non-union of long bones (analysis, risk factors, medical tactic). Ortopediya, travmatologiya i protezirovanie 2005; 2: 61-65.

7. Travmatologiya $i$ ortopediya. T. 3 [Traumatology and orthopedics. Vol. 3]. Pod red. Kornilova N.V., Gryaznukhina E.G.
[Kornilov N.V., Gryaznukhin E.G. (editors)]. Saint Petersburg; 2006.

8. Pavlov D.V., Vorob'eva O.V. Clinical and biomechanical assessment of staticodynamic indicators after endoprosthesis replacement of the ankle joint. Voprosy travmatologii i ortopedii 2012; 4(5): 7-11.

9. Segal A.D., Shofer J., Hahn M.E. Functional limitations associated with end-stage ankle arthritis. J Bone Joint Surg Am 2012 May; 94(9): 777-783, http://dx.doi.org/10.2106/JBJS. K.01177.

10. Glazebrook M., Daniels T., Younger A., Foote C.J., Penner M., Wing K., Lau J., Leighton R., Dunbar M. Comparison of health-related quality of life between patients with end-stage ankle and hip arthrosis. J Bone Joint Surg Am 2008 Mar; 90(3): 499-505, http://dx.doi.org/10.2106/JBJS.F.01299.

11. Thomas R.H., Daniels T.R. Ankle arthritis. J Bone Joint Surg Am 2003; 85(5): 923-936.

12. Valderrabano V., Hintermann B., Horisberger M., Fung T.S. Ligamentous posttraumatic ankle osteoarthritis. Am J Sports Med 2006 Apr; 34(4): 612-620, http://dx.doi.org/10.1 177/0363546505281813.

13. Leontaritis N., Hinojosa L., Panchbhavi V.K. Arthroscopically detected intra-articular lesions associated with acute ankle fractures. J Bone Joint Surg Am 2009 Feb; 91(2): 333-339, http://dx.doi.org/10.2106/JBJS.H.00584.

14. Kezlya O.P., Khar'kovich I.I., Yarmolovich V.A., Ben'ko A.N. Perelomy zadnego kraya distal'nogo metaepifiza bol'shebertsovoy kosti. V kn.: Sovremennye problemy travmatologii $i$ ortopedii [Fracture of the posterior border of the distal metaepiphysis of the tibia. In: Current issues of traumatology and orthopedics]. Voronezh; 2004; p. 124-126.

15. Gayko G.V., Brusko A.T., Limar E.V. Osteoarthritis - a new approach to prevention. Visnyk ortopedii, travmatologii ta protezuvanyja 2005; 2: 5-11.

16. Safranyuk V.M., Vlasov D.V., Stel'makh V.V. Complications of extracortical osteosynthesis for fractures of long bones and clavicle fractures. Travma 2005; 6(2): 149-153.

17. Berkes M.B., Little M.T.M., Lazaro L.E., Pardee N.C., Schottel P.C., Helfet D.L., Lorich D.G. Articular congruity is associated with short-term clinical outcomes of operatively treated SER IV ankle fractures. J Bone Joint Surg Am 2013 Oct; 95(19): 1769-1775, http://dx.doi.org/10.2106/JBJS. L.00949.

18. Noh J.H., Roh Y.H., Yang B.G., Kim S.W., Lee J.S., Oh M.K. Outcomes of operative treatment of unstable ankle fractures: a comparison of metallic and biodegradable implants. J Bone Joint Surg Am 2012 Nov; 94(22): e166, http://dx.doi. org/10.2106/JBJS.K.01221.

19. Gubanov A.V. Results of operative treatment of malleolar fractures. Molodoy uchenyy 2011; 3(2): 165-167.

20. Ryudi T.P., Barkli R.E., Moran K.G. AO - printsipy lecheniya perelomov. T. 2. Chastnaya travmatologiya [AO principles of fracture management. Vol. 2. Specific fractures]. Minsk: Vassamedia; 2013.

21. Pakarinen H., Laine H.J., Ristiniemi J. When is ankle fracture treatable without surgery? Duodecim 2012; 128(17): 1770-1776.

22. Egol K.A., Tejwani N.C., Walsh M.G., Capla E.L., Koval K.J. Predictors of short-term functional outcome following ankle fracture surgery. J Bone Joint Surg Am 2006 May; 88(5): 974-979, http://dx.doi.org/10.2106/JBJS.E.00343.

23. Herscovici D.Jr., Anglen J.O., Archdeacon M., Cannada L., Scaduto J.M. Avoiding complications in the 
treatment of pronation-external rotation ankle fractures, syndesmotic injuries, and talar neck fractures. J Bone Joint Surg Am 2008 Apr; 90(4): 898-908.

24. Siegel J., Tornetta P. 3rd. Extraperiosteal plating of pronation-abduction ankle fractures. J Bone Joint Surg Am 2008 Mar; 90(Suppl 2. Part 1): 135-144, http://dx.doi. org/10.2106/JBJS.G.01138.

25. Tornetta P. 3rd. Competence of the deltoid ligament in bimalleolar ankle fractures after medial malleolar fixation. J Bone Joint Surg Am 2000 Jun; 82(6): 843-843.

26. Wan S., Hong Y., Tian J.Q., Jiang Z., Rao X.H., Liu X.M., Wu Y. Treatment of the distal fibula fractures with intramedullary Kirschner fixation. Zhongguo Gu Shang 2013 Jan; 26(1): 78-81.

27. Kotel'nikov G.P., Mironov S.P. Travmatologiya. Natsional'noe rukovodstvo [Traumatology. National guidelines]. Moscow: Geotar-Media; 2008.

28. Blinov S.V., Malyshev E.E., Kolesov S.N., Malyshev E.S., Pavlov D.V., Muravina N.L. Temperature response of knee joint tissues in postoperative period in intraarticular fractures of condyles of tibia. Sovremennye tehnologii v medicine 2011; 4: $177-180$.

29. Still G.P., Atwood T.C. Operative outcome of 41 ankle fractures: a retrospective analysis. J Foot Ankle Surg 2009 May-Jun; 48(3): 330-339, http://dx.doi.org/10.1053/ j.jfas.2009.02.005.

30. Xu H., Li X., Zhang D., Fu Z., Wang T., Zhang P., et al. A retrospective study of posterior malleolus fractures. Int Orthop 2012; 36(9): 1929-1936, http://dx.doi.org/10.1007/ s00264-012-1591-9.

31. Lamontagne J., Blachut P.A., Broekhuyse H.M., O'Brien P.J., Meek R.N. Surgical treatment of a displaced lateral malleolus fracture: the antiglide technique versus lateral plate fixation. J Orthop Trauma 2002; 16(7): 498-502.

32. Femino J.E., Vaseenon T. The direct lateral approach to the distal tibia and fibula: a single incision technique for distal tibial and pilon fractures. lowa Orthop J 2009; 29: 143-148.

33. De Leeuw P.A., Golany P., Sierevelt I.N., van Dijk C.N. The course of the superficial peroneal nerve in relation to the ankle position: anatomical study with ankle arthroscopic implications. Knee Surg Sports Traumatol Arthrosc 2010; 18(5): 612-617, http://dx.doi.org/10.1007/s00167-010-1099-z.

34. Beekman R., Tracy Watson J. Bosworth fracturedislocation and resultant compartment syndrome. J Bone Joint Surg Am 2003 Nov; 85(11): 2211-2214.

35. Yao Q., Ni J., Peng L.B., Yu D.X., Yuan X.M. Locked plating with minimally invasive percutaneous plate osteosynthesis versus intramedullary nailing of distal fibula fracture: a retrospective study. Zhonghua Yi Xue Za Zhi 2013 Dec; 93(47): 3748-3751.

36. Liu Y.W., Kuang Y., Gu X.F., Zheng Y.X., Li Z.Q., Wei X.E., Zhang M.C., Zhan H.S., Shi Y.Y. Close reduction combined with minimally invasive percutaneous plate osteosynthesis for proximal and distal fibula fractures: a report of 56 patients. Zhongguo Gu Shang 2013 Mar; 26(3): 248-251.

37. Pires R.E., Mauffrey C., de Andrade M.A., Figueiredo L.B., Giordano V., Belloti J.C., dos Reis F.B. Minimally invasive percutaneous plate osteosynthesis for ankle fractures: a prospective observational cohort study. Eur $J$ Orthop Surg Traumatol 2014 Aug; 24(7): 1297-1303, http:// dx.doi.org/10.1007/s00590-013-1295-x.

38. Kim H.J., Oh J.K., Hwang J.H., Park Y.H. The use of
T-LCP (locking compression plate) for the treatment of the lateral malleolar fractures. Eur J Orthop Surg Traumatol 2013 Feb; 23(2): 233-237, http://dx.doi.org/10.1007/s00590-0120952-9.

39. Shmidt R., Benesh S. Biomechanical consequences of anatomical reconstruction of the lateral ligaments to the ankle joint complex: an in vitro investigation. Travmatologiya $i$ ortopediya Rossii 2013; 3(69): 72-79.

40. Krips R., van Dijk C.N., Halasi T., Lehtonen $H_{\text {., }}$ Moyen B., Lanzetta A., Farkas T., Karlsson J. Anatomical reconstruction versus tenodesis for the treatment of chronic anterolateral instability of the ankle joint: a 2- to 10-year follow-up, multicenter study. Knee Surg Sports Traumatol Arthrosc 2000; 8(3): 173-179, http://dx.doi.org/10.1007/ s001670050210.

41. Walther M., Kriegelstein S., Altenberger S., Volkering C., Röser A., Wölfel R. Lateral ligament injuries of the ankle joint. Der Unfallchirurg 2013 Sep; 116(9): 776-780, http://dx.doi. org/10.1007/s00113-013-2383-4.

42. Krips R., van Dijk C.N., Halasi P.T., Lehtonen H., Corradini C., Moyen B., Karlsson J. Long-term outcome of anatomical reconstruction versus tenodesis for the treatment of chronic anterolateral instability of the ankle joint: a multicenter study. Foot Ankle Int 2001; 22(5): 415-421.

43. Abdelgawad A.A., Kadous A., Kanlic E. Posterolateral approach for treatment of posterior malleolus fracture of the ankle. J Foot Ankle Surg 2011; 50(5): 607-611, http://dx.doi. org/10.1053/j.jfas.2011.04.022.

44. Forberger J., Sabandal P.V., Dietrich M., Gralla J., Lattmann T., Platz A. Posterolateral approach to the displaced posterior malleolus: functional outcome and local morbidity. Foot Ankle Int 2009; 30(4): 309-314, http://dx.doi.org/10.3113/ FAl.2009.0309.

45. Jowett A.J., Sheikh F.T., Carare R.O., Goodwin M.I. Location of the sural nerve during posterolateral approach to the ankle. Foot Ankle Int 2010; 31(10): 880-883, http://dx.doi. org/10.3113/FAl.2010.0880.

46. Tornetta P. 3rd., Ricci W., Nork S., Collinge C., Steen B. The posterolateral approach to the tibia for displaced posterior malleolar injuries. J Orthop Trauma 2011; 25(2): 123-126, http://dx.doi.org/10.1097/BOT.0b013e3181e47d29.

47. Fu S., Zou Z.Y., Mei G., Jin D. Advances and disputes of posterior malleolus fracture. Chin Med J (Engl) 2013 Oct; 126(20): 3972-3977.

48. Mohammed R., Syed S., Metikala S., Ali S.A Evaluation of the syndesmotic-only fixation for Weber-C ankle fractures with syndesmotic injury. Indian J Orthop 2011 Sep-Oct; 45(5): 454-458, http://dx.doi.org/10.4103/0019-5413.83953.

49. DeGroot H., Al-Omari A.A., El Ghazaly S.A. Outcomes of suture button repair of the distal tibiofibular syndesmosis. Foot Ankle Int 2011; 32(3): 250-256, http://dx.doi.org/10.3113/ fai.2011.0250.

50. Forsythe K., Freedman K.B., Stover M.D., Patwardhan A.G. Comparison of a novel fiber wire-button construct versus metallic screw fixation in a syndesmotic injury model. Foot Ankle Int 2008; 29(1): 49-54, http://dx.doi. org/10.3113/FAI.2008.0049.

51. Klitzman R., Zhao H., Zhang L.-Q., Strohmeyer G., Vora A. Suture-button versus screw fixation of the syndesmosis: a biomechanical analysis. Foot Ankle Int 2010; 31(1): 69-75, http://dx.doi.org/10.3113/FAl.2010.0069.

52. Hamid N., Loeffler B.J., Braddy W., Kellam J.F., Cohen B.E., Bosse M.J. Outcome after fixation of ankle 
fractures with an injury to the syndesmosis: the effect of the syndesmosis screw. J Bone Joint Surg Br 2009; 91(8): 10691073, http://dx.doi.org/10.1302/0301-620X.91B8.22430.

53. Lambers K.T.A., van den Bekerom M.P.J., Doornberg J.N., Stufkens S.A.S., van Dijk C.N., Kloen P. Long-term outcome of pronation-external rotation ankle fractures treated with syndesmotic screws only. J Bone Joint Surg Am 2013 Sep; 95(17): e1221-1227, http://dx.doi. org/10.2106/JBJS.L.00426.

54. Jindal N., Gupta P. Comment on $X u$ et al.: a retrospective study of posterior malleolus fractures. Int Orthop 2013 May; 37(5): 993-994, http://dx.doi.org/10.1007/s00264013-1785-9.

55. Hunt K.J. Syndesmosis injuries. Curr Rev Musculoskelet Med 2013 Dec; 6(4): 304-312, http://dx.doi.org/10.1007/ s12178-013-9184-9.

56. Chen D.W., Li B., Yang Y.F., Yu G.R. Torsional stiffness in supplemental one-third tubular plate fixation for isolated syndesmosis injuries. Foot Ankle Int 2013 Sep; 34(9): 1320, http://dx.doi.org/10.1177/1071100713496225.

57. Parada S.A., Krieg J.C., Benirschke S.K., Nork S.E. Bicortical fixation of medial malleolar fractures. Am J Orthop (Belle Mead NJ) 2013; 42(2): 90-92.

58. Fowler T.T., Pugh K.J., Litsky A.S., Taylor B.C., French B.G. Medial malleolar fractures: a biomechanical study of fixation techniques. Orthopedics 2011; 34(8): e349-e355, http://dx.doi.org/10.3928/01477447-20110627-09.

59. Kupcha P., Pappas S. Medial malleolar fixation with a bicortical screw: technique tip. Foot Ankle Int 2008; 29(11): 1151-1153, http://dx.doi.org/10.3113/FAl.2008.1151.

60. Ebraheim N.A., Ludwig T., Weston J.T., Carroll T., Liu J. Comparison of surgical techniques of 111 medial malleolar fractures classified by fracture geometry. Foot Ankle Int 2014 May; 35(5): 471-477, http://dx.doi.org/10.1177/107110071452 4553.

61. Stufkens S.A.S., van den Bekerom M.P.J., Knupp M., Hintermann B., van Dijk C.N. The diagnosis and treatment of deltoid ligament lesions in supination-external rotation ankle fractures: a review. Strategies Trauma Limb Reconstr 2012 Aug; 7(2): 73-85, http://dx.doi.org/10.1007/s11751-012-0140-9.

62. Hobson S.A., Karantana A., Dhar S. Total ankle replacement in patient with significant pre-operative deformity of the hindfoot. J Bone Joint Surg Br 2009 Apr; 91(4): 481-486, http://dx.doi.org/10.1302/0301-620X.91B4.20855.

63. Kumar A., Dhar S. Total ankle replacement: early results during learing period. Foot Ankle Surg 2007; 13(1): 19-23, http://dx.doi.org/10.1016/j.fas.2006.06.002.

64. Stoyanov A.V., Emelyanov V.G., Pliev D.G., Mikhaylov K.S. Ankle joint replacement. Travmatologiya $i$ ortopediya Rossii 2011; 1: 144-152.

65. Hintermann B., Barg A. Mid- to long-term survivorship of Hintegra total ankle. In: Presented at the American Academy of Orthopaedic Surgeons $76^{\text {th }}$ annual meeting. Las Vegas; 2009; p. 25-27.

66. Lee K.T., Lee Y.K., Young K.W., Kim H.J., Park S.Y., Kim J.S., Kim K.C. Perioperative complications of the MOBILITY total ankle system: comparison with the HINTEGRA total ankle system. J Orthop Sci 2010 May; 15(3): 317-322, http://dx.doi.org/10.1007/s00776-010-1456-2.

67. Havelin L.I., Fenstad A.M., Salomonsson R., Mehnert F., Furnes O., Overgaard S., Pedersen A.B., Herberts P., Kärrholm J., Garellick G. The Nordic Arthroplasty Register Association: a unique collaboration between
3 national hip arthroplastyregistries with 280,201 THRs. Acta Orthop 2009; 80(4): 393-401, http://dx.doi.org/10.3109/ 17453670903039544.

68. Andersson T., Montgomery F., Carlsson A. Uncemented STAR total ankle prostheses. Three to eight-year follow-up of fifty-one consecutive ankles. J Bone Joint Surg Am 2003; 85(7): 1321-1329.

69. Wood P.L., Deakin S. Total ankle replacement. The result in 200 ankles. J Bone Joint Surg $\mathrm{Br}$ 2003; 85(3): 334-341.

70. McGarvey W.C., Clanton T.O., Lunz D. Malleolar fracture after ankle arthroplasty: a comparison of designs. Clin Orth Relat Res 2004; 424: 104-110, http://dx.doi. org/10.1097/01.blo.0000131202.58536.89.

71. Buechel F.F.Sr., Buechel F.F.Jr., Pappas M.J. Twentyyear evaluation of cementless mobile-bearing total ankle replacements. Clin Orthop Relat Res 2004 Jul; 424: 19-26, http://dx.doi.org/10.1097/01.blo.0000132243.41419.59.

72. Koefoed H. Scandinavian total ankle replacement (STAR). Clin Orthop Relat Res 2004; 424: 73-79, http://dx.doi. org/10.1097/01.blo.0000132414.41124.06.

73. Yang J.H., Kim H.J., Yoon J.-R., Yoon Y.-C. Minimally invasive plate osteosynthesis (MIPO) for periprosthetic fracture after total ankle arthroplasty: a case report. Foot Ankle Int 2011 Feb; 32(2): 200-204, http://dx.doi.org/10.3113/FAl.2011.0200.

74. Labek G., Todorov S., Iovanescu L., Stoica C.I., Böhler N. Outcome after total ankle arthroplasty — results and findings from worldwide arthroplasty registers. Int Orthop 2013 Sep; 37(9): 1677-1682, http://dx.doi.org/10.1007/s00264-0131981-7.

75. Iorio R., Robb W.J., Healy W.L., Berry D.J., Hozack W.J., Kyle R.F., Lewallen D.G., Trousdale R.T., Jiranek W.A., Stamos V.P., Parsley B.S. Orthopaedic surgeon workforce and volume assessment for total hip and knee replacement. J Bone Joint Surg Am 2008 Jul; 90(7): 1598-1605, http://dx.doi. org/10.2106/JBJS.H.00067.

76. Arkhipov S.V., Lychagin A.V. Modern aspects of treatment of post-traumatic ankle joint arthrosis deformans. Vestnik travmatologii i ortopedii im. N.N. Priorova 2000; 4: 64-67.

77. Stoyanov A.V. Khirurgicheskoe lechenie bol'nykh s zastarelymi pronatsionnymi podvyvikhami v golenostopnom sustave (kliniko-eksperimental'noe issledovanie). Avtoref. dis. ... kand. med. nauk [Surgical treatment of patients with old pronation subluxation of the ankle joint (clinical-experimental study). Abstract of Dissertation for the degree of Candidate Medical Science]. Saint Petersburg; 2005.

78. Roukis T.S. Corrective ankle osteotomies. Clin Podiatry Med Surg 2004 Jul; 21(3): 353-370, http://dx.doi.org/10.1016/ j.cpm.2004.03.007.

79. Giannini S., Buda R., Faldini C., Vannini F., Romagnoli M., Grandi G., Bevoni R. The treatment of severe posttraumatic arthritis of the ankle joint. J Bone Joint Surg Am 2007 Oct; 89(Suppl 3): 15-28, http://dx.doi.org/10.2106/JBJS. G.00544.

80. Rammelt S., Marti R.K., Zwipp H. Joint-preserving osteotomy of malunited ankle and pilon fractures. Der Unfallchirurg 2013 Sep; 116(9): 789-796, http://dx.doi. org/10.1007/s00113-013-2385-2.

81. Barg A., Pagenstert G., Leumann A., Valderrabano V. Malleolar osteotomy — osteotomy as approach. Der Orthopäde 2013 May; 42(5): 309-321, http://dx.doi.org/10.1007/s00132012-2007-7. 
82. Malyshev E.E., Varvarin O.P., Korolev S.B., Vaganov B.V. Sposob plastiki kostnogo defekta epimetafiza bol'shebertsovoy kosti [Method of bone defect plasty in tibial epimetaphys]. Patent RU 2309691. 2006.

83. Arkhipov S.V., Lychagin A.V. Lechenie deformiruyushchego artroza golenostopnogo sustava artroskopicheskim metodom. V kn.: Minimal'no-invazivnye $i$ endoskopicheskie tekhnologii $v$ travmatologii $i$ ortopedii [Treatment of post-traumatic ankle joint arthrosis deformans using an arthroscopic method. In: Minimally invasive and endoscopic techniques in traumatology and orthopedics]. Yalta; 2002.

84. Musalatov Kh.A., Arkhipov S.V., Lychagin A.V. Khirurgicheskoe lechenie degenerativno-distroficheskikh zabolevaniy golenostopnogo sustava artroskopicheskim metodom. V kn.: Materialy VII s"ezda travmatologov-ortopedov Rossii [Surgical treatment of ankle joint degenerative-dystrophic diseases using an arthroscopic method. In: Materials of VIII Congress of traumatologists and orthopedists of Russia]. Novosibirsk; 2002.

85. Donnenwerth M.P., Roukis T.S. Outcome of arthroscopic debridement and microfracture as the primary treatment for osteochondral lesions of the talar dome. Arthroscopy 2012 Dec; 28(12): 1902-1907, http://dx.doi.org/10.1016/ j.arthro.2012.04.055.

86. Hepple S., Guha A. The role of ankle arthroscopy in acute ankle injuries of the athlete. Foot Ankle Clin 2013 Jun; 18(2): 185-194, http://dx.doi.org/10.1016/j.fcl.2013.02.001.

87. Giza E., Howell S. Allograft juvenile articular cartilage transplantation for treatmentof talus osteochondral defects. Foot Ankle Spec 2013 Apr; 6(2): 141-144, http://dx.doi.org/10. 1177/1938640013479934.

88. Giza E., Sullivan M., Ocel D., Lundeen G., Mitchell M.E., Veris L., Walton J. Matrix-induced autologous chondrocyte implantation of talus articular defects. Foot Ankle Int 2010 Sep; 31(9): 747-753, http://dx.doi.org/10.3113/FAI.2010.0747.

89. Van Bergen C.J., de Leeuw P.A., van Dijk C.N. Treatment of osteochondral defects of the talus. Rev Chir Orthop Reparatrice Appar Mot 2008 Dec; 94(8 Suppl): 398408, http://dx.doi.org/10.1016/j.rco.2008.09.003.

90. Merian M., Easley M. Diagnosis and treatment of osteochondral lesions of the talus. Der Orthopäde 2008 Mar; 37(3): 204-211, http://dx.doi.org/10.1007/s00132-008-1219-3.

91. Murawski C.D., Kennedy J.G. Operative treatment of osteochondral lesions of the talus. J Bone Joint Surg Am 2013 Jun; 95(11): 1045-1054, http://dx.doi.org/ 10.2106/JBJS. L.00773.

92. Coester L.M., Saltzman C.L., Leupold J., Pontarelli W. Long term results following ankle arthrodesis for post- traumatic arthritis. J Bone Joint Surg Am 2001; 83(2): 219-228. 93. Chopra S., Rouhani H., Assal M., Aminian K., Crevoisier X. Outcome of unilateral ankle arthrodesis and total anklereplacement in terms of bilateral gait mechanics. J Orthop Res 2014 Mar; 32(3): 377-384, http://dx.doi.org/10.1002/ jor.22520.

94. Thomas R., Daniels T.R., Parker K. Gait analysis and functional outcomes following ankle arthrodesis for isolated ankle arthritis. J Bone Joint Surg Am 2006 Mar; 88(3): 526535, http://dx.doi.org/10.2106/JBJS.E.00521.

95. Onodera T., Majima T., Kasahara Y., Takahashi D., Yamazaki S., Ando R., Minami A. Outcome of transfibular ankle arthrodesis with Ilizarov apparatus. Foot Ankle Int 2012 Nov; 33(11): 964-968, http://dx.doi.org/10.3113/fai.2012.0964.

96. Khanfour A.A. Versatility of llizarov technique in difficult cases of ankle arthrodesis and review of literature. Foot Ankle Surg 2013 Mar; 19(1): 42-47, http://dx.doi.org/10.1016/ j.fas.2012.10.001.

97. Fedorov V.G. Arthrodesis of the ankle joint using millingcutter. Travmatologiya i ortopediya Rossii 2010; 1: 99-101.

98. Jehan S., Shakeel M., Bing A.J., Hill S.O. The success of tibiotalocalcaneal arthrodesis with intramedullary nailing - a systematic review of the literature. Acta Orthop Belg 2011 Oct; 77(5): 644-651.

99. Hyer C.F., Cheney N. Anatomic aspects of tibiotalocalcaneal nail arthrodesis. J Foot Ankle Surg 2013 Nov-Dec; 52(6): 724-727, http://dx.doi.org/10.1053/ j.jfas.2013.06.018.

100. Gross J.-B., Belleville R., Nespola A., Poircuitte J.-M., Coudane H., Mainard D., Galois L. Influencing factors of functional result and bone union in tibiotalocalcaneal arthrodesis with intramedullary locking nail: a retrospective series of 30 cases. Eur J Orthop Surg Traumatol 2014 May; 24(4): 627-633, http://dx.doi.org/10.1007/s00590-013-1347-2.

101. Popelka S., Vavřík P., Landor I., Bek J., Popelka ml S., Hromádka R. Tibio-talo-calcaneal arthrodesis with the retrograde intramedullary nail MEDIN. Acta Chir Orthop Traumatol Cech 2013; 80(6): 400-406.

102. Richter M., Evers J., Waehnert D., DeOrio J.K., Pinzur M., Schulze M., Zech S., Ochman S. Biomechanical comparison of stability of tibiotalocalcaneal arthrodesis with two different intramedullary retrograde nails. Foot Ankle Surg 2014 Mar; 20(1): 14-19, http://dx.doi.org/10.1016/ j.fas.2013.08.003.

103. Richter M., Geerling J., Frink M., Zech S. Computerassisted surgery (CAS) based correction of posttraumatic ankle and hindfoot deformities - preliminary results. Foot and Ankle Surgery 2006; 12(3): 113-119, http:Hdx.doi.org/10.1016/ j.fas.2006.02.003. 